\title{
Perancangan Sistem Informasi Otorisasi Aktifitas Ruang Server
}

\author{
Agni Isador Harsapranata \\ Fakultas Ekonomi dan Bisnis Universitas Bina Sarana Informatika \\ Website: www.bsi.ac.id ,E-mail: agni.aih@bsi.ac.id
}

\begin{abstract}
Abstrak - Dengan pesatnya perkembangan teknologi komputer dewasa ini, mendorong penulis untuk melakukan penelitian di bidang sistem informasi. Dimana dalam sistem informasi yang penulis lakukan yaitu dengan adanya masalah yang terjadi didalam penulis melakukan monitoring terhadap seluruh aktifitas ruang server.Dalam hal ini penulis selama ini penulis kesulitan dalam melakukan pencatatan seluruh aktifitas yang dilakukan di dalam ruang server. Karena apabila tidak diakukan pencatatan seluruh aktifitas yang dilakukan di ruang server, mengakibatkan terjadinya kerja server yang tidak dapat dikontrol dan konfigurasi yang tidak standard yang dilakukan oleh administrator. Dengan adanya sistem informasi ini dapat memonitor apa saja yang telah dilakukan, dan server mana saja yang perlu mendapatkan perhatian lebih oleh administrator. Dalam pembuatan sistem informasi ini penulis memanfaatkan aplikasi open source berbasis web, dimana bahasa pemrograman yang digunakan adalah Php, web server yang digunakan menggunakan Apache dan memanfaatkan database Mysql. Dengan memanfaatkan apliasi open source berbasis web, menjadikan aplikasi ini dapat dipasang di server manapun, dan dapat diakses menggunakan berbagai macam sistem operasi termasuk juga menggunakan smartphone.
\end{abstract}

Kata Kunci: Open Source, Php, Mysql, Sistem Informasi

\begin{abstract}
With the rapid development of computer technology today, it encourages authors to conduct research in the field of information systems. Where in the information system that the author does is with a problem that occurs in the writer monitoring all server room activities. In this case the author has had difficulty recording all activities carried out in the server room. Because if it does not record all activities carried out in the server room, it will result in server work that cannot be controlled and non-standard configurations carried out by the administrator. With this information system, it can monitor what has been done, and which servers need more attention by the administrator. In making this information system the author uses a web-based open source application, where the programming language used is Php, the web server used is Apache and utilizes the Mysql database. By utilizing a web-based open source application, this application can be installed on any server, and can be accessed using various operating systems including using a smartphone.
\end{abstract}

Keyword: Open Source, Php, Mysql, Information System

\section{PENDAHULUAN}

Dewasa ini penggunakan teknologi sudah sangat maju, baik dilihat dari perkembangan software, hardware, dan networking. Demikian juga di dalam organisasi bisnis, tidak dapat dipisahkan dari pemanfaatan perkembangan teknologi ini. Salah satu yang penulis tuangkan dalam penelitian ini adalah pemanfaatan sistem informasi dalam mendukung operasional organisasi bisnis. Dalam hal ini penulis memanfaatkan teknologi tersebut dipergunakan untuk melakukan monitoring terhadap berbagai macam aktifitas di dalam ruang server. Ada beberapa alasan kenapa ruang server sangat penting dilakukan pengawasan, karena di dalam ruangan tersebut tersimpan berbagai macam mesin yang mendukung berjalannya organisasi bisnis, bisa dibayangkan apabila mesin yang berada di ruang server tersebut berhenti beroperasi karena ada kesalahan dalam tindakan atau kelalaian yang di lakukan akibat tidak di awasi dengan baik oleh administrator ataupun pihak manajemen. Mengakibatkan terhentinya proses bisnis yang sedang dilakukan oleh suatu organisasi yang dapat merugikan.

Kegiatan pencatatan yang dilakukan oleh administrator selama ini dilakukan secara manual menggunakan aplikasi excel, dimana hanya dimonitor dan dipergunakan oleh satu orang administrator, 
sehinga akan menyulitkan apabila akan dilakukan pemeriksaan ulang oleh administrator yang lain.

Ruang lingkup penelitian ini dibatasi oleh pengembangan sistem informasi yang dipergunakan oleh administrator jaringan dalam melakukan monitoring berbagai macam aktifitas yang dilakukan didalam ruang server diketahui oleh manajemen.

\section{LANDASAN TEORI}

\subsection{Pengertian Perancangan}

"Rancang merupakan serangkaian prosedur untuk menerjemahkan hasil analisa dari sebuah sistem ke dalam bahasa pemrograman untuk mendeskripsikan dengan detail bagaimana komponen komponen sistem diimplementasikan" [1].

\subsection{Pengertian Sistem Informasi}

"Sistem Informasi sebagai berikut. Sistem informasi adalah suatu sistem di dalam suatu organisasi yang mempertemukan kebutuhan pengolahan transaksi harian, mendukung operasi, bersifat manajerial dan kegiatan strategi dari suatu organisasi dan menyediakan pihak luar tertentu dengan laporan-laporan yang diperlukan" [2].

"Sistem informasi terdiri dari komponenkomponen yang disebutnya dengan istilah blok bangunan (building block), yaitu blok masukan (input block), blok model (model block), blok keluaran (output block), blok teknologi (technology block), blok basis data (database block), dan blok kendali (controls block), Sebagai suatu sistem keenam blok tersebut masing-masing saling berinteraksi satu dengan yang lainnya membentuk satu kesatuan untuk mencapai sasarannya, seperti terlihat di Gambar 1" [2].

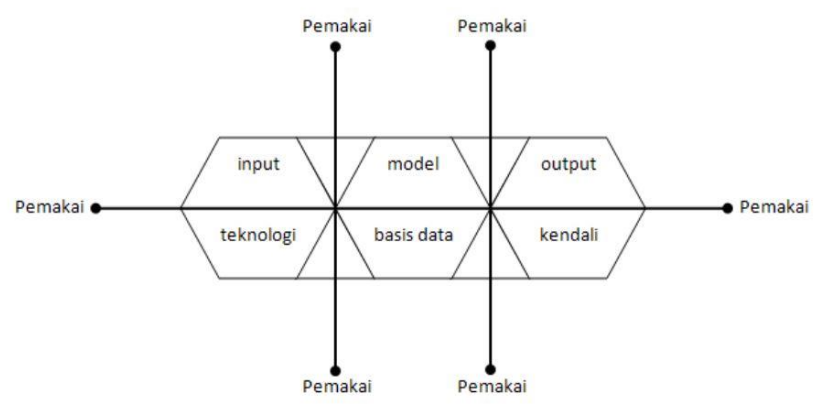

Gambar 1 Blok Sistem informasi yang berinteraksi [2]

\subsection{Model Pengembangan Perangkat Lunak}

Pada penelitian kali ini penulis menggunakan metode Waterfall dalam pengembangan system informasi ini. Metode waterfall adalah metode air terjun menyediakan pendekatan alur hidup perangkat

Copyright (C) 2020 FT-UHAMKA. - All rights reserved DOI: 10.22236/teknoka.v5i.316 lunak secara sekuensial atau terurut dimulai dari analisa, desain, pengkodean, pengujian, dan pendukung [3].

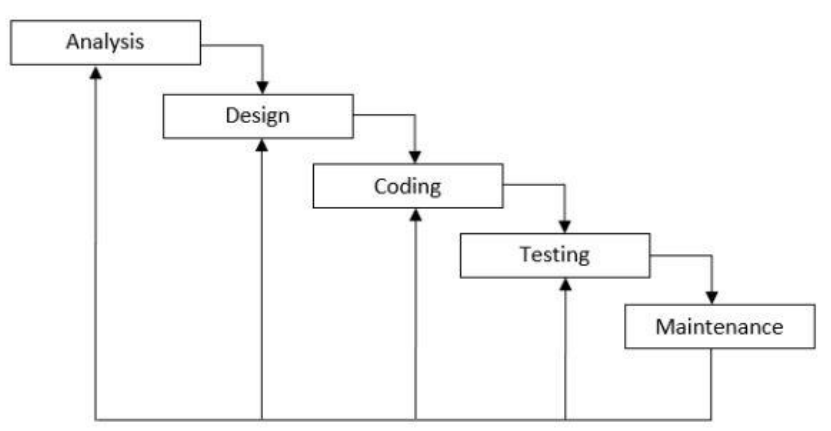

Gambar 2 Metode Waterfall [3]

Dalam [4], Terdapat 5 tahapan pada model waterfall yang ditunjukkan pada gambar 2 .

\section{a. Requirement Analysis and Definition}

Pada tahap analisa sistem, penulis menggunakan pendekatan berorientasi obyek, dengan menggunakan diagram UML. Pada proses analisa, teknis yang digunakan adalah:

1) Analisa Perilaku Sistem

Pada tahap ini, dilakukan analisa sistem yang sedang berjalan digambarkan menggunakan diagram flow.

2) Analisa Data dan Informasi Sistem Berjalan Analisa dilihat dari prosedur yang berada di dalam sistem dan seluruh dokumen penyerta di dalam sistem yang sudah berjalan.

b. System and Software Design

Dalam tahapan ini penulis membuat suatu pemodelan untuk sistem (UML), menentukan rancangan database, serta membuat prototype (desain) sistem.

\section{c. Implementation and Unit Testing}

Dalam langkah ini, seluruh diagram yang telah di buat saat melakukan analisa, dituangkan ke dalam program dan dilakukan percobaan terhadap setiap aplikasi, dan dilakukan penilaian apakah dapat berjalan sesuai dengan berbagai macam diagram perancangan.

\section{d. Integration and System Testing}

Dalam langkah ini, seluruh aplikasi yang sudah lolos terhadap percobaan oleh bagian test, akan dilakukan integrasi secara keseluruhan, dan tetap dilakukan testing, apakah seluruh program yang terdiri dari sub sub aplikasi dapat berjalan sesuai dengan kebutuhan. 


\section{e. Operation and Maintenance}

Dalam langkah terakhir adalah dilakukan pengoperasian aplikasi secara keseluruhan dan di coba oleh pemakai, dan setelah berjalan dilakukan maintenance dan dinilai apakah ada perbaikan atau peningkatan yang harus dilakukan oleh penulis.

\subsection{Unified Modeling Language}

"Unified Modeling Language adalah sebuah bahasa yang berdasarkan gambar untuk menvisualisasikan, menspesifikasikan, membangun dan pendokumentasian dari sebuah sistem pengembangan perangkat lunak berbasis Objek" [5].

\section{a. Use Case Diagram}

"Use case diagram merupakan pemodelan untuk kelakuan sistem informasi yang akan dibuat. Use case bekerja dengan mendeskripsikan tipikal interaksi antara user sebuah sistem dengan sistemnnya sendiri melalui sebuah cerita bagaimana sistem itu dipakai" [5].

\section{b. Class Diagram}

"Class diagram merupakan gambaran struktur sistem dari segi pendefinisian kelas-kelas yang akan dibuat untuk membangun sistem. Class diagram terdiri dari atribut dan operasi dengan tujuan pembuat pembuat program dapat membuat hubungan antara dokumentasi perancangan dan perangkat lunak sesuai. [5]"

\section{c. Sequence Diagram}

"Sequence diagram menggambarkan kelakuan objek pada use case dengan mendeskripsikan waktu hidup objek dan pesan yang dikirimkan dan diterima antar objek. Gambaran sequence diagram dibuat minimal sebanyak pendefinisan use case yang memiliki proses sendiri atau yang penting semua use case yang telah didefinisikan interaksi jalannya pesan sudah dicakup pada sequence diagram sehingga semakin banyak use case yang didefinisikan, maka sequence diagram yang harus dibuat juga semakin banyak" [5].

\section{d. Activity Diagram}

"Activity diagram merupakan diagram yang menggambarkkan workflow atau aktivitas dari sebuah sistem yang ada pada perangkat lunak" [5].

\section{PERANCANGAN SISTEM}

Perancangan sistem yang digunakan pada penelitian ini terdiri dari metode dalam pengumpulan data, dan metode perancangan sistem.

\subsection{Metode Pengumpulan Data}

a. Observasi

Penulis melakukan pengamatan secara langsung terhadap berbagai sistem berjalan yang ada dalam pencatatan berbagai aktifitas yang dilakukan di dalam ruang server.

b. Wawancara

Penulis melakukan tanya jawab terhadap administrator ruang server mengenai berbagai macam dokumen dan prosedur yang harus dilakukan sebelum dan sesudah seorang administrator melakukan aktifitas di dalam ruang server.

\section{c. Kepustakaan}

Disini penulis merangkumberbagai macam sumber informasi rujukan yang berhubungan dengan topik penelitian ini.

\subsection{Metode Perancangan Sistem}

Dalam metode Perancangan Sistem Informasi Otorisasi Aktifitas Ruang Server di penelitian ini, penulis menggunakan metode waterfall yang terdiri dari lima tahap berikut ini [3]:

\section{a. Requirement Analysis and Definition}

Pada tahap ini penulis melakukan riset langsung di perusahaan yang sudah memiliki data center yang selalu online selama 24 jam tanpa henti, untuk menganalisa sistem yang sedang berjalan agar diketahui prosedur yang harus dijalankan apabila seorang administrator akan melakukan berbagai kegiatan di dalam ruang server, baik untuk melakukan penambahan, perbaikan, dan perawatan berbagai macam peralatan didalam ruang server.

\section{b. System and Software Design}

Dalam tahapan ini akan dibuat rancangan alur sistem dengan menggunakan UML, lalu dibuat design antar muka dan rancangan database dengan menggunakan MySQL. Pembuatan web sistem informasi ini menggunakan bahasa pemrograman PHP, dan notepad ++ sebagai editornya.

\section{c. Implementation and Unit Testing}

Dalam tahapan ini, program yang terdiri dari kode dan database sistem Perancangan Sistem Informasi Otorisasi Aktifitas Ruang Server akan Seminar Nasional TEKNOKA ke - 5, Vol. 5, 2020 ISSN No. 2502-8782 
diimplementasikan dan setiap bagian sistem akan diuji untuk memastikan semua bagian telah berfungsi secara baik, dan memastikan tidak terjadi kesalahan.

\section{d. Integration and System Testing}

Dalam tahapan ini, program yang terdiri dari kode dan database sistem di upload ke dalam server, yang nantinya aplikasi tersebut akan dipergunakan oleh internal perusahaan sebagai alat kontrol terhadap berbagai macam aktifitas administrator di dalam ruang server.

\section{e. Operation and Maintenance}

Agar sistem yang dibangun selalu dalam kondisi yang baik dan dapat dipergunakan dengan baik, perlu di lakukan perawatan, baik dalam bentuk update sistem operasi, upgrade hardware server, dan perbaikan terus menerus terhadap sistem yang sudah di bangun. Dengan adanya operation dan maintenance, menjadikan aplikasi yang dibangun semakin memenuhi kebutuhan manajemen terhadap kontrol server yang semakin baik, dan dapat di pertanggungjawabkan.

\section{IMPLEMENTASI DAN PENGUJIAN}

Analisa pemodelan.

\subsection{Use Case Diagram}

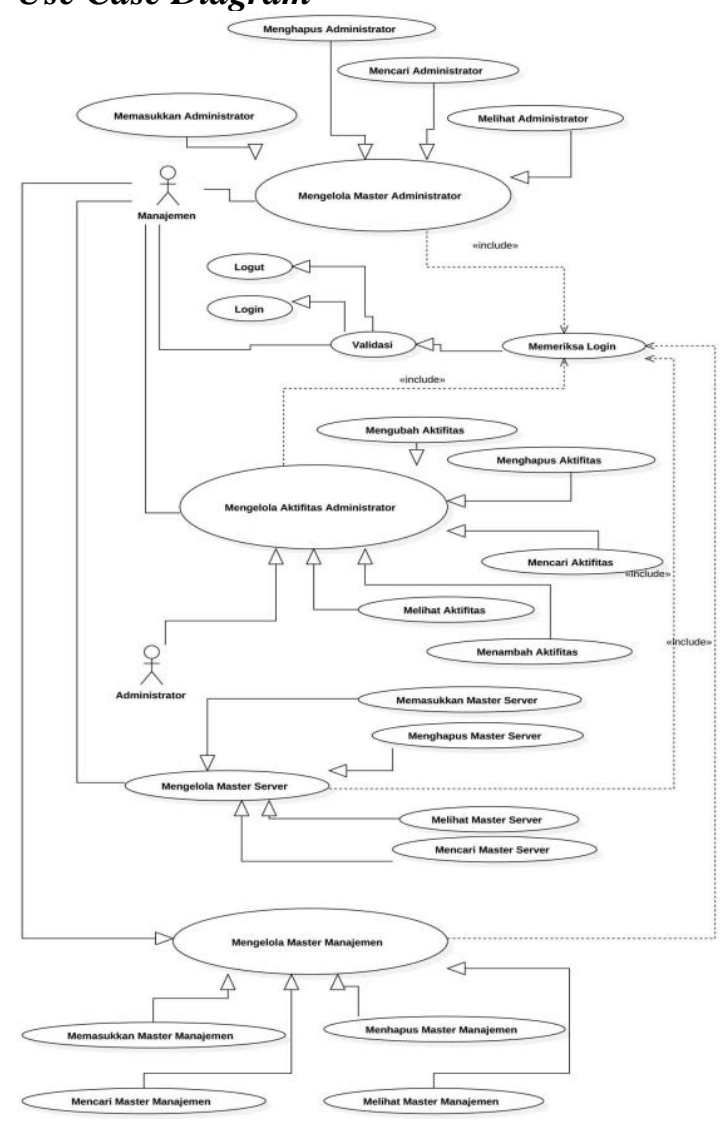

Copyright (C) 2020 FT-UHAMKA. - All rights reserved DOI: 10.22236/teknoka.v5i.316

\section{Gambar 3 Use Case Perancangan Sistem Informasi Otorisasi Aktifitas Ruang Server}

a. Definis Aktor

Berikut adalah penjelasan dari aktor pada Use Case Perancangan Sistem Informasi Otorisasi Aktifitas Ruang Server seperti terlihat di gambar 3, dijelaskan pada Tabel 1.

Tabel 1 Penjelasan Aktor

\begin{tabular}{|l|l|l|}
\hline No & \multicolumn{1}{|c|}{ Aktor } & \multicolumn{1}{c|}{ Penjelasan } \\
\hline 1 & Manajemen & $\begin{array}{l}\text { Orang yang memiliki hak akses secara penuh } \\
\text { terhadap pengelolaan sistem pencatanan } \\
\text { aktifitas administrator di dalam ruang server }\end{array}$ \\
\hline 2 & Administrator & $\begin{array}{l}\text { Adalah orang yang diberikan otoritas dalam } \\
\text { melakukan pencatanan berbagai macam } \\
\text { aktifitas di dalam ruang server, baik dalam } \\
\text { melakukan penambahan, perawatan, } \\
\text { perbaikan, berbagai macam peralatan yang } \\
\text { berada didalam ruang server. }\end{array}$ \\
\hline
\end{tabular}

b. Definisi Use Case

Tabel 2 Use Case

\begin{tabular}{|c|c|c|}
\hline No & Use Case & Penjelasan \\
\hline 1 & Validasi & $\begin{array}{l}\text { Adalah langkah pemeriksaan otoriasasi, siapa } \\
\text { yang mendapat ijin untuk melakukan proses } \\
\text { pengelolaan data. Dalam hal ini semua proses } \\
\text { sistem informasi otorisasi aktifitas ruang } \\
\text { server diwajibkan untuk melewati validasi. }\end{array}$ \\
\hline 2 & Login & $\begin{array}{l}\text { Adalah langkah dalam melakukan login ke } \\
\text { dalam sistem, baik dilakukan oleh } \\
\text { administrator dan manajemen. }\end{array}$ \\
\hline 3 & Logout & $\begin{array}{l}\text { Adalah langkah dalam keluar dari aplikasi, } \\
\text { baik dilakukan oleh administrator ataupun } \\
\text { dilakukan oleh manajemen. }\end{array}$ \\
\hline 4 & Memeriksa Login & $\begin{array}{l}\text { Merupakan Proses dari sistem, untuk } \\
\text { melakukan pemeriksaan pengguna, apakah } \\
\text { sudah melewati validasi login atau belum. }\end{array}$ \\
\hline 5 & $\begin{array}{l}\text { Mengelola } \\
\text { Administrator }\end{array}$ & $\begin{array}{l}\text { Mengelola Master Administrator, merupakan } \\
\text { proses generalisasi yang meliputi proses } \\
\text { memasukkan administrator, menghapus } \\
\text { administrator, mencari administrator, dan } \\
\text { melihat administrator. }\end{array}$ \\
\hline 6 & $\begin{array}{l}\text { Memasukkan } \\
\text { Administrator }\end{array}$ & $\begin{array}{l}\text { Merupakan proses memasukkan data } \\
\text { Administrator ke dalam sistem informasi } \\
\text { otorisasi aktifitas ruang server. }\end{array}$ \\
\hline 7 & $\begin{array}{l}\text { Menghapus } \\
\text { Administrator }\end{array}$ & $\begin{array}{l}\text { Merupakan proses menghapus data } \\
\text { Administrator ke dalam sistem informasi } \\
\text { otorisasi aktifitas ruang server. }\end{array}$ \\
\hline 8 & Mencari Administrator & $\begin{array}{l}\text { Merupakan proses } \\
\text { Administrator di dalam sistem informasi } \\
\text { otorisasi aktifitas ruang server. }\end{array}$ \\
\hline 9 & Melihat Administrator & $\begin{array}{l}\text { Merupakan proses melihat data Administrator } \\
\text { di dalam sistem informasi otorisasi aktifitas } \\
\text { ruang server. }\end{array}$ \\
\hline 10 & $\begin{array}{ll}\text { Mengelola } & \text { Aktifitas } \\
\text { Administrator } & \end{array}$ & $\begin{array}{l}\text { Mengelola Aktifitas Administrator, } \\
\text { merupakan proses generalisasi yang meliputi } \\
\text { proses mengubah aktifitas administrator, } \\
\text { menghapus aktifitas administrator, mencari } \\
\text { aktifitas administrator, dan melihat aktifitas } \\
\text { administrator. }\end{array}$ \\
\hline 11 & Mengubah Aktifitas & $\begin{array}{l}\text { Merupakan proses mengubah data Aktifitas } \\
\text { Administrator di dalam sistem informasi } \\
\text { otorisasi aktifitas ruang server. }\end{array}$ \\
\hline 12 & Menghapus Aktifitas & $\begin{array}{l}\text { Merupakan proses menghapus data Aktifitas } \\
\text { Administrator di dalam sistem informasi } \\
\text { otorisasi aktifitas ruang server. }\end{array}$ \\
\hline 13 & Mencari Aktifitas & $\begin{array}{l}\text { Merupakan proses mencari data Aktifitas } \\
\text { Administrator di dalam sistem informasi } \\
\text { otorisasi aktifitas ruang server. }\end{array}$ \\
\hline 14 & Menambah Aktifitas & $\begin{array}{l}\text { Merupakan proses menambah data Aktifitas } \\
\text { Administrator di dalam sistem informasi } \\
\text { otorisasi aktifitas ruang server. }\end{array}$ \\
\hline 15 & Melihat Aktifitas & $\begin{array}{l}\text { Merupakan proses melihat data Aktifitas } \\
\text { Administrator di dalam sistem informasi } \\
\text { otorisasi aktifitas ruang server. }\end{array}$ \\
\hline
\end{tabular}

Seminar Nasional TEKNOKA ke - 5, Vol. 5, 2020 ISSN No. 2502-8782 


\begin{tabular}{|c|c|c|}
\hline 16 & Mengelola Master Server & $\begin{array}{l}\text { Mengelola Master Server, merupakan proses } \\
\text { generalisasi yang meliputi proses } \\
\text { memasukkan master server, menghapus } \\
\text { master server, melihat master server, dan } \\
\text { mencari master server. }\end{array}$ \\
\hline 17 & $\begin{array}{l}\text { Memasukkan Master } \\
\text { Server }\end{array}$ & $\begin{array}{l}\text { Merupakan proses memasukkan data master } \\
\text { server ke dalam sistem informasi otorisasi } \\
\text { aktifitas ruang server. }\end{array}$ \\
\hline 18 & $\begin{array}{l}\text { Menghapus } \\
\text { Server }\end{array}$ & $\begin{array}{l}\text { Merupakan proses menghapus data master } \\
\text { server di dalam sistem informasi otorisasi } \\
\text { aktifitas ruang server. }\end{array}$ \\
\hline 19 & Melihat Master Server & $\begin{array}{l}\text { Merupakan proses melihat data master server } \\
\text { di dalam sistem informasi otorisasi aktifitas } \\
\text { ruang server. }\end{array}$ \\
\hline 20 & Mencari Master Server & $\begin{array}{l}\text { Merupakan proses mencari data master server } \\
\text { di dalam sistem informasi otorisasi aktifitas } \\
\text { ruang server. }\end{array}$ \\
\hline 21 & $\begin{array}{l}\text { Mengelola } \\
\text { Manajemen }\end{array}$ & $\begin{array}{l}\text { Mengelola Master Manajemen, merupakan } \\
\text { proses generalisasi yang meliputi proses } \\
\text { memasukkan master manajemen, mencari } \\
\text { master manajemen, menghapus master } \\
\text { manajemen, dan melihat master manajemen. }\end{array}$ \\
\hline 22 & $\begin{array}{l}\text { Memasukkan } \\
\text { Manajemen }\end{array}$ & $\begin{array}{l}\text { Merupakan proses memasukkan data master } \\
\text { Manajemen ke dalam sistem informasi } \\
\text { otorisasi aktifitas ruang server. }\end{array}$ \\
\hline 23 & $\begin{array}{l}\text { Mencari } \\
\text { Manajemen }\end{array}$ & $\begin{array}{l}\text { Merupakan proses mencari data master } \\
\text { Manajemen di dalam sistem informasi } \\
\text { otorisasi aktifitas ruang server. }\end{array}$ \\
\hline 24 & $\begin{array}{l}\text { Menghapus } \\
\text { Manajemen }\end{array}$ & $\begin{array}{l}\text { Merupakan proses menghapus data master } \\
\text { Manajemen di dalam sistem informasi } \\
\text { otorisasi aktifitas ruang server. }\end{array}$ \\
\hline 25 & $\begin{array}{l}\text { Melihat } \\
\text { Manajemen }\end{array}$ & $\begin{array}{l}\text { Merupakan proses melihat data master } \\
\text { Manajemen di dalam sistem informasi } \\
\text { otorisasi aktifitas ruang server. }\end{array}$ \\
\hline
\end{tabular}

\subsection{Class Diagram}

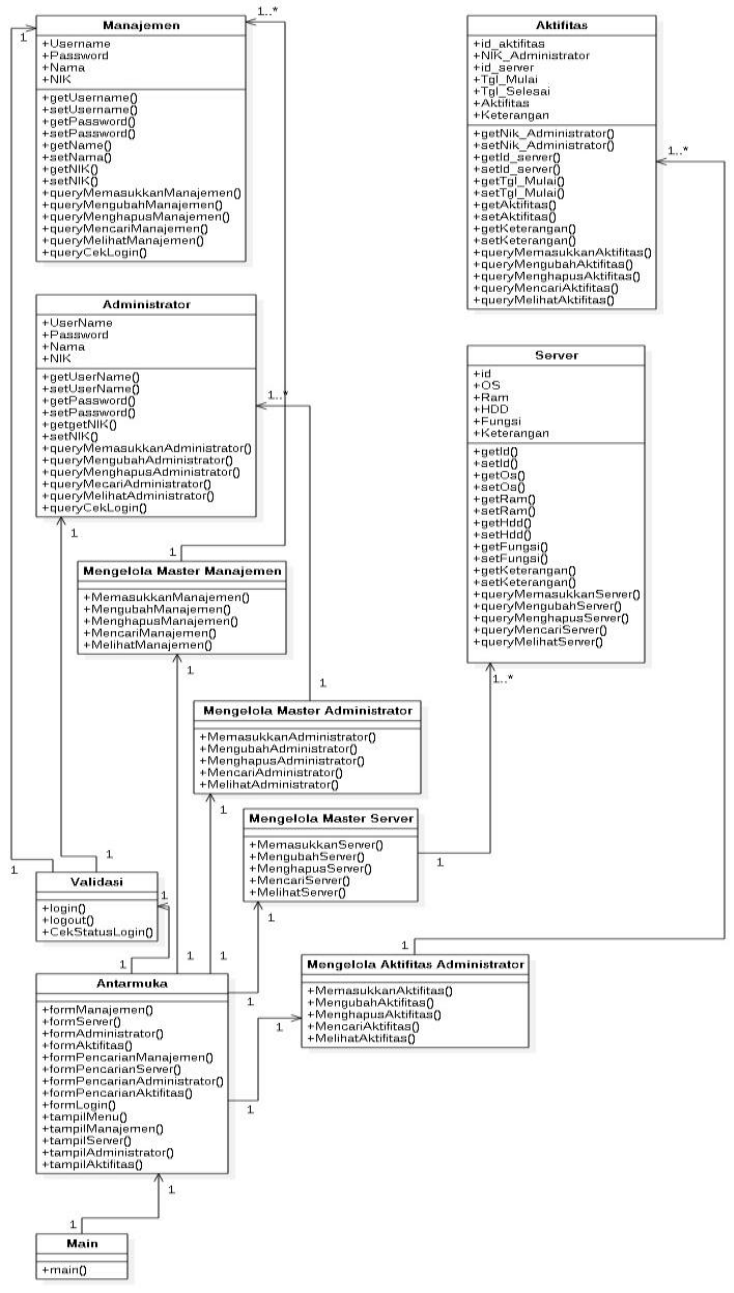

Copyright $@ 2020$ FT-UHAMKA. - All rights reserved DOI: $10.22236 /$ teknoka.v5i.316
Gambar 4 Class Diagram Perancangan Sistem Informasi Otorisasi Aktifitas Ruang Server

Tabel 3 Penjelasan Class Diagram

\begin{tabular}{|c|c|}
\hline Nama Kelas & Keterangan \\
\hline Main & $\begin{array}{l}\text { Adalah kelas yang diakses pertama kali } \\
\text { sebagai pintu gerbang utama } \\
\text { menjalankan aplikasi }\end{array}$ \\
\hline Antarmuka & $\begin{array}{l}\text { Adalah kelas yang memberikan layanan } \\
\text { tampilan }\end{array}$ \\
\hline Mengelola Aktifitas Administrator & $\begin{array}{l}\text { Adalah kelas proses yang merupakan } \\
\text { definisi dari } \text { use case mengelola aktifitas } \\
\text { administrator yang didalamnya harus } \\
\text { juga menangani proses memasukkan } \\
\text { aktifitas administrator, mengubah } \\
\text { aktifitas administrator, menghapus } \\
\text { aktifitas administrator, mencari aktifitas } \\
\text { administrator, dan melihat aktifitas } \\
\text { administrator }\end{array}$ \\
\hline Validasi & $\begin{array}{l}\text { Adalah mernupakan kelas pemerikasaan } \\
\text { pengguna, apakah mendapat otorisasi } \\
\text { untuk masuk ke aplikasi atau tidak }\end{array}$ \\
\hline Mengelola Master Server & $\begin{array}{l}\text { Adalah kelas yang menjalankan } \\
\text { pengelolaan master server yang } \\
\text { didalamnya harus juga menangani } \\
\text { proses memasukkan master server, } \\
\text { mengubah master server, menghapus } \\
\text { master server, mencari master server, } \\
\text { dan melihat master server }\end{array}$ \\
\hline Mengelola Master Administrator & $\begin{array}{lrr}\text { Adalah kelas } & \text { yang } & \text { menjalankan } \\
\text { pengelolaan } & \text { master administrator yang } \\
\text { didalamnya harus juga } & \text { menangani } \\
\text { proses } & \text { memasukkan } & \text { master } \\
\text { administrator, mengubah } & \text { master } \\
\text { administrator, menghapus } & \text { master } \\
\text { administrator, mencari } & \text { master } \\
\text { administrator, dan melihat } & \text { master } \\
\text { administrator } & & \end{array}$ \\
\hline Mengelola Master Manajemen & $\begin{array}{l}\text { Adalah kelas yang menjalankan } \\
\text { pengelolaan master manajemen yang } \\
\text { didalamnya harus juga menangani } \\
\text { proses memasukkan master manajemen, } \\
\text { mengubah master manajemen, } \\
\text { menghapus master manajemen, mencari } \\
\text { master manajemen, dan melihat master } \\
\text { manajemen }\end{array}$ \\
\hline Administrator & $\begin{array}{l}\text { Adalah kelas data yang digunakan untuk } \\
\text { memproses segala pengaksesan terhadap } \\
\text { tabel administrator }\end{array}$ \\
\hline Server & $\begin{array}{l}\text { Adalah kelas data yang digunakan untuk } \\
\text { memproses segala pengaksesan terhadap } \\
\text { tabel server }\end{array}$ \\
\hline Manajemen & $\begin{array}{l}\text { Adalah kelas data yang digunakan untuk } \\
\text { memproses segala pengaksesan terhadap } \\
\text { tabel manajemen }\end{array}$ \\
\hline Aktifitas & $\begin{array}{l}\text { Adalah kelas data yang digunakan untuk } \\
\text { memproses segala pengaksesan terhadap } \\
\text { tabel aktifitas }\end{array}$ \\
\hline
\end{tabular}

Dari Gambar 4 Class Diagram Perancangan Sistem Informasi Otorisasi Aktifitas Ruang Server, dijelaskan setiap class di Tabel 3.

\subsection{Sequence Diagram}

Dalam penulisan ini penulis menggambarkan login, logout, dan sequence diagram yang berhubungan dengan aktifitas administrator.

a. Berikut adalah sequence diagram untuk use case login, dapat dilihat di gambar 5. 


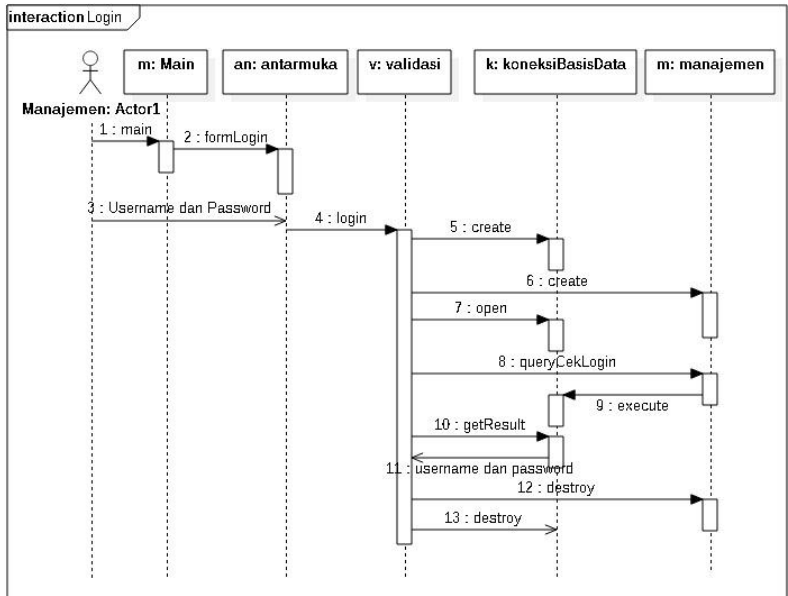

Gambar 5 Sequence Diagram Login

b. Sequence diagram untuk use case logout, seperti terlihat di gambar 6 .

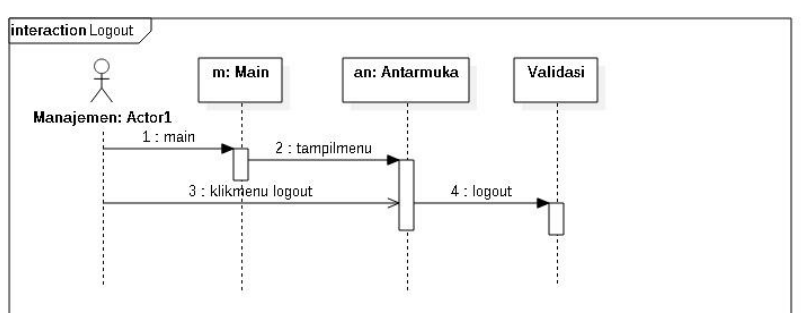

Gambar 6 Sequence Diagram Logout

c. Sequence diagram untuk use case memasukkan aktifitas dapat dilihat di gambar 7 .

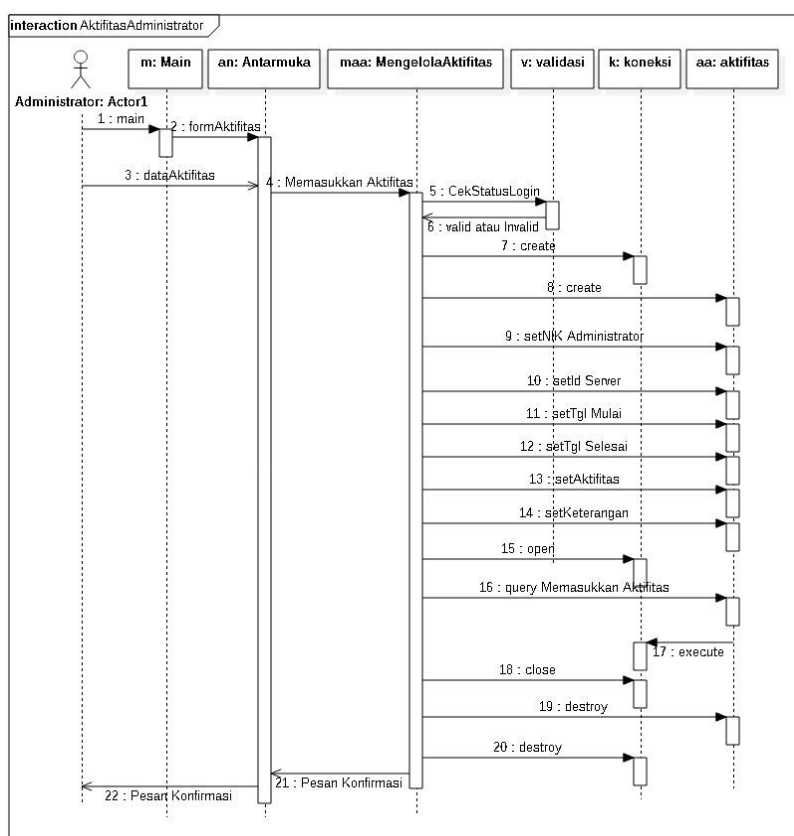

Gambar 7 Sequence Diagram Memasukkan Aktifitas

d. Sequence diagram untuk use case mengubah aktifitas dapat dilihat di gambar 8 .

Copyright $(02020$ FT-UHAMKA. - All rights reserved DOI: 10.22236/teknoka.v5i.316

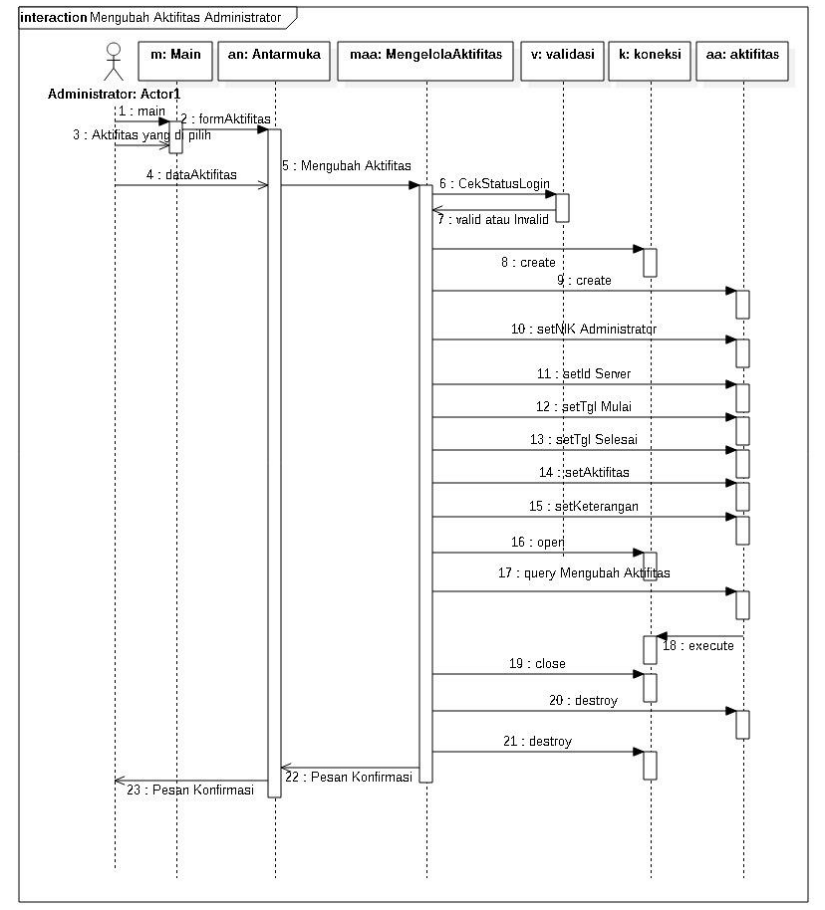

Gambar 8 Sequence Diagram Mengubah Aktifitas

e. Sequence diagram untuk use case mencari aktifitas dapat dilihat di gambar 9.

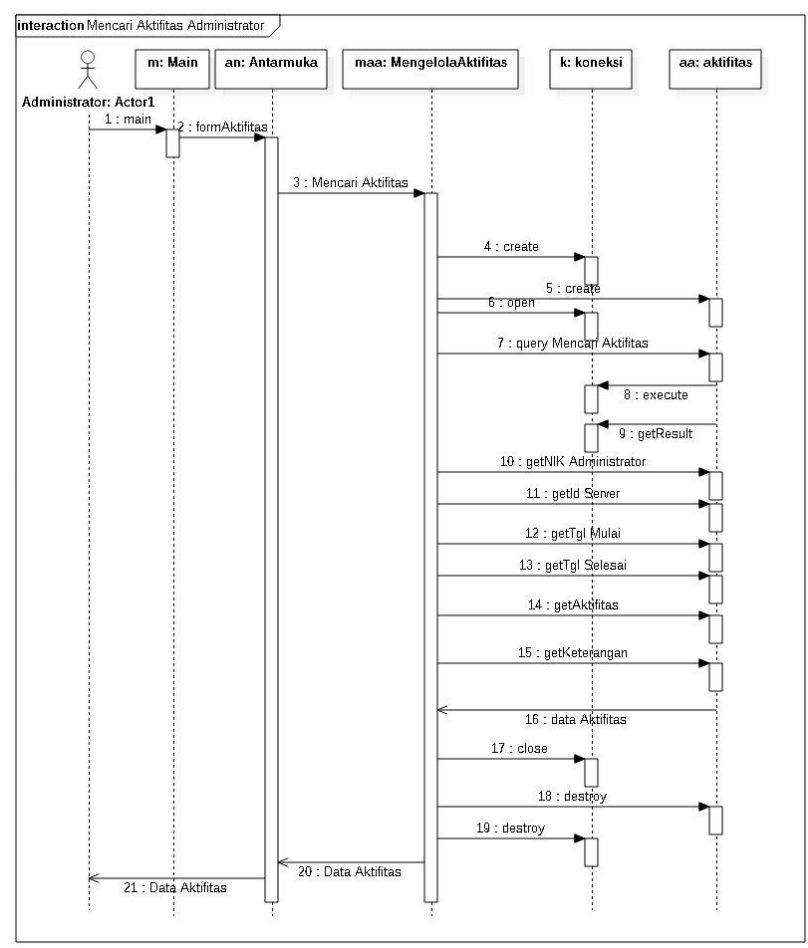

Gambar 9 Sequence Diagram Mencari Aktifitas

f. Sequence diagram untuk use case menghapus aktifitas dapat dilihat di gambar 10 . 


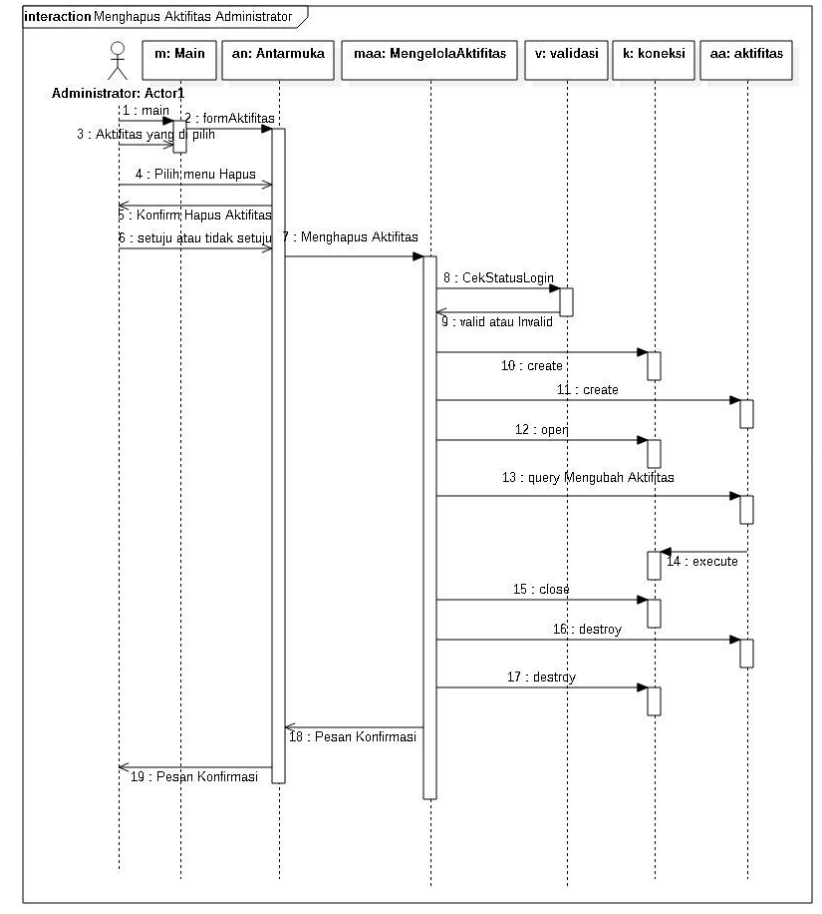

Gambar 10 Sequence Diagram Menghapus Aktifitas

g. Sequence diagram untuk use case melihat aktifitas dapat dilihat di gambar 11.

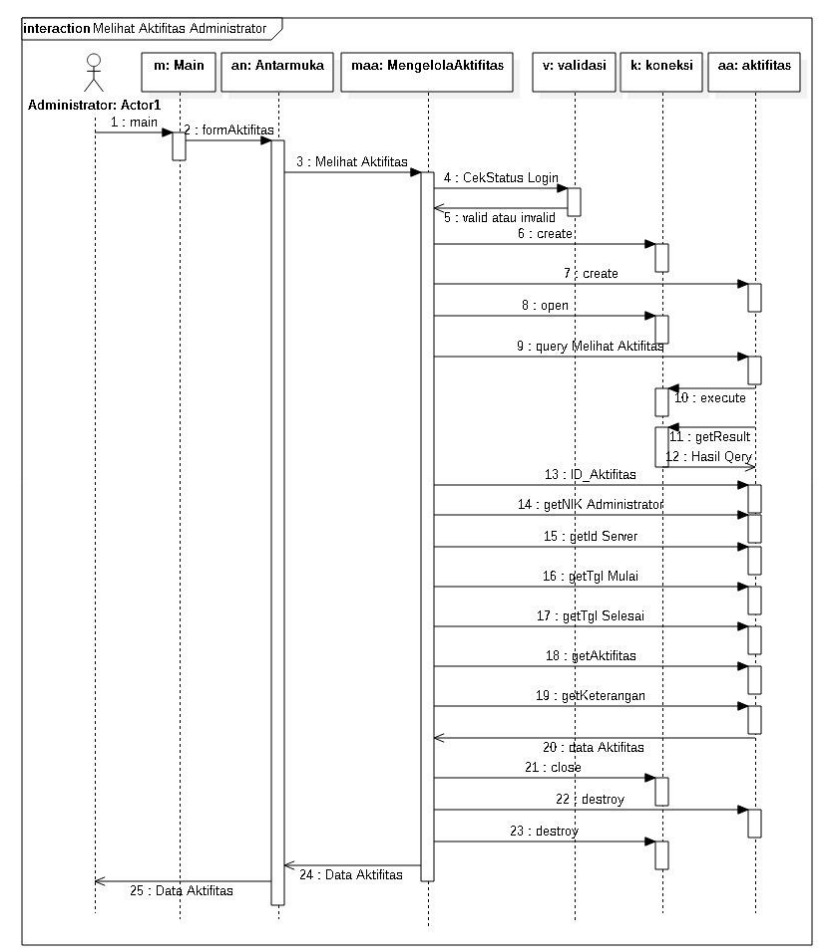

Gambar 11 Sequence Diagram Melihat Aktifitas

\subsection{Activity Diagram}

Dalam penelitian ini penulis menggambarkan 2 activity diagram, yaitu activity diagram dari sisi manajemen dan activity diagram dari sisi

Copyright (C) 2020 FT-UHAMKA. - All rights reserved DOI: 10.22236/teknoka.v5i.316 administrator. Activity diagram manajemen dapat dilihat di gambar 12, dan activity diagram administrator dapat dilihat di gambar 13 .

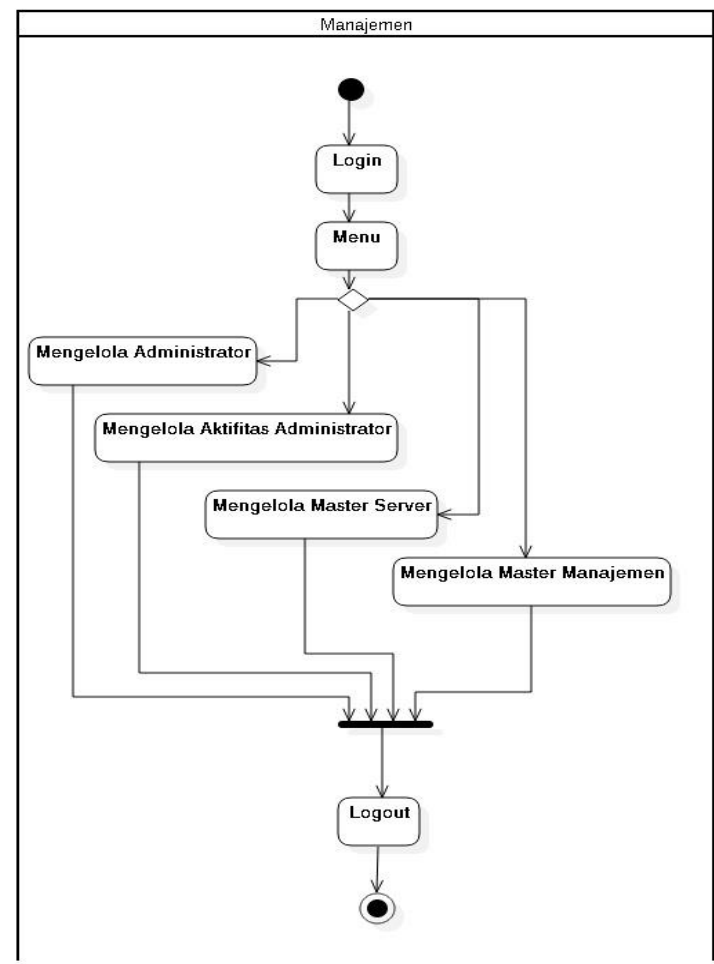

Gambar 12 Activity Diagram Manajemen

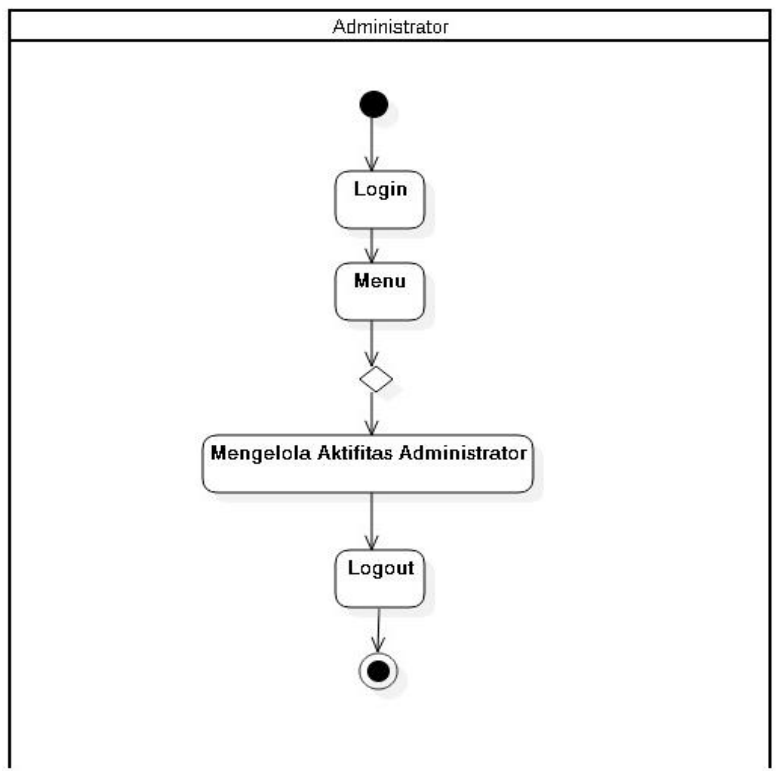

Gambar 13 Activity Diagram Administrator

\subsection{Deployment Diagram}

Seluruh aplikasi yang sudah di kodekan di deploy ke dalam mesin server, yang di dalamnya sudah terdapat aplikasi web server, dan database, seperti terlihat di gambar 14. 


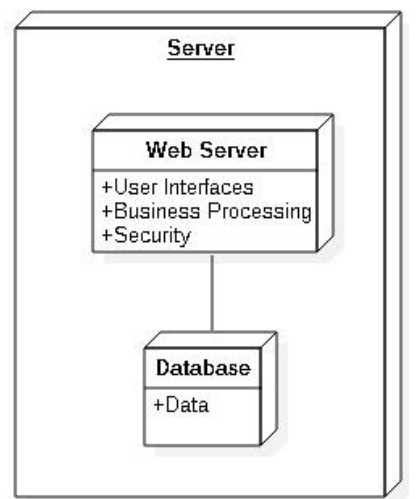

Gambar 14 Deployment Diagram Administrator

\subsection{Rancangan Interface}

a. Rancangan Form Login

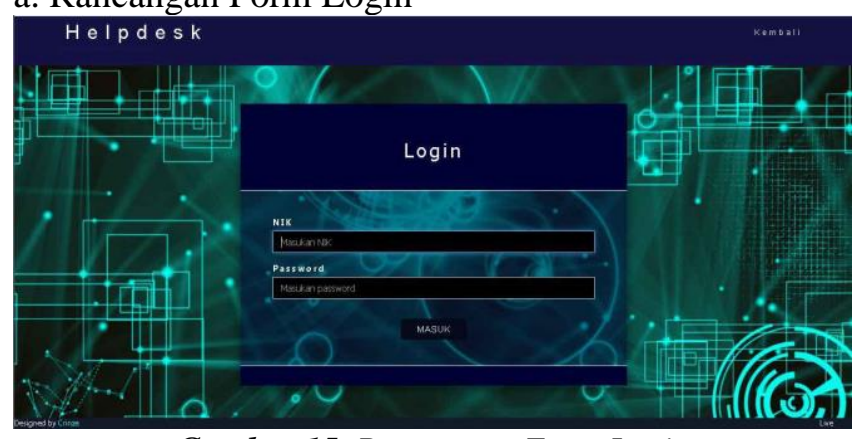

Gambar 15 Rancangan Form Login

\section{SIMPULAN}

Dari peancangan di dalam penelitian ini, penulis mengambil kesimpulan bahwa :

- Pekerjaan pengelolaan aktifitas administrator pada awalnya masih dijalankan berdasarkan intruksi manajemen ke administrator secara lisan dan didokumentasikan menggunakan kertas, sehingga sering terjadi tidak terkontrolnya perawatan terhadap setiap server.

- Dengan adanya sistem yang terkomputerisasi memudahkan manajemen dan administrator dalam melakukan monitoring dan perawatan ruang server dan berbagai perangkat didalamnya.

\section{KEPUSTAKAAN}

[1] M. Z. Buchari, S. R. Sentinuwo, and O. A. Lantang, "Rancang Bangun Video Animasi 3 Dimensi Untuk Mekanisme Pengujian Kendaraan Bermotor di Dinas Perhubungan, Kebudayaan, Pariwisata, Komunikasi dan Informasi," J. Tek. Inform., vol. 6, no. 1, pp. 16, 2015, doi: 10.35793/jti.6.1.2015.9964.

[2] Lantip Diat Prasojo, SISTEM INFORMASI MANAJEMEN PENDIDIKAN, 1st ed. Yogyakarta: UNY Press, 2013.

[3] M. S. Rosa Ariani Sukamto, Rekayasa Perangkat Lunak. Bandung: Informatika, 2013.

[4] R. Taufiq and I. S. Mustofa, "Perancangan Sistem Pendukung Keputusan Kejurusan Menggunakan Metode Simple Additive Weighting (Saw) Di Sma Negri 15 Tangerang," J. TI Atma Luhur, vol. 4, no. 1, pp. 103-114, 2017, [Online]. Available: http://jurnal.atmaluhur.ac.id/index.php/TI_atm a_luhur/article/viewFile/273/224.

[5] D. Wira, T. Putra, and R. Andriani, "Unified Modelling Language ( UML ) dalam Perancangan Sistem Informasi Permohonan Pembayaran Restitusi SPPD," J. TeknoIf, vol. 7, no. 1, 2019, [Online]. Available: https://ejournal.itp.ac.id/index.php/tinformatika /article/view/1109/754. 